\title{
A Tér és Társadalom 2011-ben
}

\section{Space and Society in 2011}

\section{CZIRFUSZ MÁRTON, TAGAI GERGELY}

A Tér és Társadalom új szerkesztősége 2011-től vette át a szerkesztési munkákat. Az elmúlt egy év tapasztalatai alapján a folyóiratot tág szakmai kör forgatja, a Tér és Társadalom a hazai regionális tudomány legfontosabb fóruma, de emellett interdiszciplináris folyóirattá nőtte ki magát az elmúlt huszonöt évben. Ennek a sokszínűségnek a bemutatására egy rövid összeállítást közlünk a folyóirat tavalyi szerzőiről és lektorairól.

\section{A folyóirat szerzói 2011 -ben}

A Tér és Társadalom 2011-es szerzőinek területi megoszlásáról (amelyet a lap elején a Szerzőink rovatban megjelent munkahely településével azonosítottunk), munkahelyük intézményi típusáról, valamint szakterületéről készítettünk összeállítást. Ez utóbbinál az MTA köztestületi tagjai esetében a tudományos bizottságot vettük figyelembe, a többieknél egyéb források (saját meghatározásuk, intézményi honlapok stb.) alapján tettük meg a besorolást. A folyóirat szerzői között szerepeltettük mindazokat, akik tavaly egyedüli vagy társszerzőként publikáltak a Tér és Társadalomban. Minden szerzőt egyszer vettünk számba, függetlenül attól, hogy hány cikk megírásában működött közre.

A szerzők munkahelyének típusáról szóló információk arról tájékoztatnak, hogy a folyóiratban publikáló kutatók milyen intézményi keretek között foglalkoznak területi kutatásokkal és a tágabb szakma tudományos életét érintő kérdésekkel (1. táblázat). A Tér és Társadalom 2011-es évfolyamának szerzői közül sokan - több mint 50\%-ban - valamely hazai (és néhány esetben külföldi) felsőoktatási intézmény oktatói és hallgatói közösségéből kerültek ki. Ugyanakkor számos szerzőnk munkája kötődik a különböző magyarországi kutatóintézetekhez. Közülük legtöbben az MTA kutatóhálózatához tartozó intézetek tagjai köztük tizennégy RKK-s kollégánk. Ezek mellett további kutatóhelyek (pl. KSH), közigazgatási és civil szervetek, de tanácsadó- és tervezőcégek is adtak szerzőket a TéT számára.

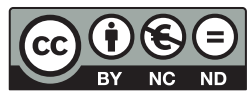


1. táblázat: A Tér és Társadalom szerzői munkahelyük intézményi típusának megoszlása szerint, 2011

Distribution of Space and Society's authors according to employer type, 2011

\begin{tabular}{lc}
\hline \multicolumn{1}{c}{ A munkahely intézményi típusa } & A szerzók száma \\
\hline Egyetem/főiskola & 48 \\
MTA Regionális Kutatások Központja & 14 \\
MTA más kutatóintézete & 7 \\
Más kutatóhely & 1 \\
Állami szféra & 3 \\
Magánszféra & 7 \\
Egyéb & 1 \\
\hline Szerzók összesen & 81 \\
\hline
\end{tabular}

Szerzőink területi megoszlásának bemutatásával azt kívántuk szemléltetni, hogy mennyire széles az a kör, amelyet sikerült megszólaltatnunk Magyarországon belül és a határokon túl (1. ábra). Örömteli, hogy számos külföldi intézményben dolgozó - bár több esetben magyar - szerző rövidebb-hosszabb írását sikerült megjelentetnünk, és nem csupán a környező országokból, hiszen svájci, mexikói, németországi és francia illetőségű szerzőink is akadtak. A magyarországi szerzők esetében elmondható, hogy a munkahelyek intézményi típusainak arányai nagyban meghatározzák a szerzők területi megoszlását is. Minthogy 2011-ben a Tér és Társadalom legtöbb szerzője valamely hazai felsőoktatási

1. ábra: A Tér és Társadalom szerzőinek (munkahelyek szerinti) területi megoszlása, 2011

Spatial distribution of Space and Society's authors (according to workplace), 2011

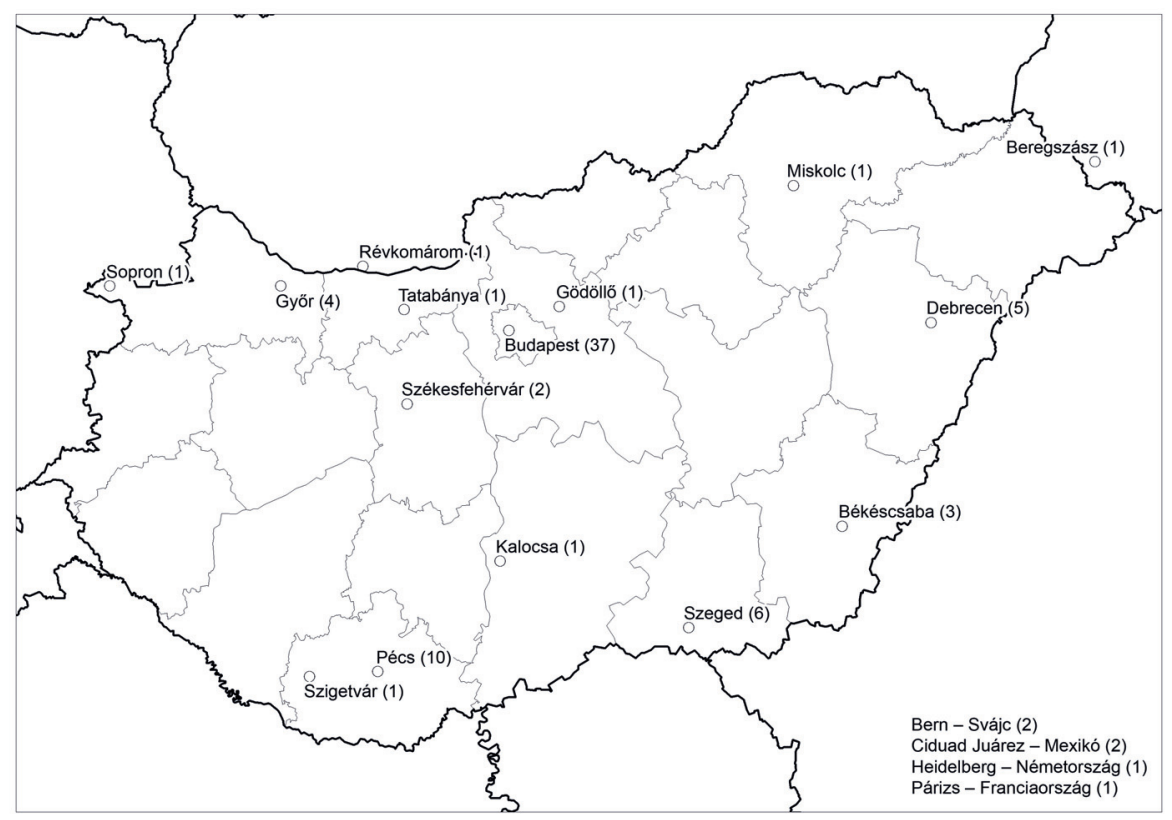


intézmény vagy kutatóintézet kötelékében állt, így ezek országon belüli fekvése leképezi szerzőink területi elhelyezkedését is. A nagyobb vidéki felsőoktatási központok (Pécs, Szeged, Debrecen, Miskolc és Győr) mellett további vidéki egyetemek és főiskolák (Sopron, Tatabánya, Gödöllő, Kalocsa) néhány oktatója/kutatója is gazdagította a folyóirat szerzői közösségét. Szerzőink majdnem fele ezek mellett is budapesti illetőségű; fővárosi egyetemeken, kutatóintézetekben és egyéb szervezeteknél dolgozik. (2012-ig) egyetlen nem budapesti központú, de országos hálózattal rendelkező kutatóintézetként a Regionális Kutatások Központja adott Budapesten kívülről szerzőket a kutatói szférából: 2011-ben győri, székesfehérvári, pécsi és békéscsabai kollégáink írásai is megjelentek a TéT-ben.

Tavalyi nyolcvanegy szerzőnk változatos szakterületeket képviselt (2. táblázat). Ez összhangban állt a 2011/1-es szám szerkesztőségi beköszöntőjében megfogalmazott törekvéssel, hogy a Tér és Társadalom ne beszükült szakmai kör lapja legyen, hanem a rokonszakmák felé is nyitott maradjon. Amellett, hogy a TéT a Regionális Kutatások Központjának kiadványa, és így a hazai regionális tudomány folyóirata (pl. azzal is, hogy a Magyar Regionális Tudományi Társaság illetménylapja), a szerzők között csak kisebb számban találunk regionalistákat. Ez betudható annak, hogy Magyarországon még kevés kutató határozza meg magát a regionális tudomány képviselőjeként (például az MTA Regionális Tudományok Bizottsága is az újabb MTA-bizottságok közé tartozik), területi kérdésekkel - elméleti felvetésekkel és gyakorlati problémákkal egyaránt - más szakterületek kutatói foglalkoznak jelentős számban. Mindenekelőtt a társadalomföldrajzé, amelyet harminchárom szerzőnk képviselt. De emellett olyan rokontudományok is nagyobb számban adtak szerzőket a Tér és Társadalom tavalyi évfolyama számára, mint a közgazdaságtan, a szociológia vagy az urbanisztika, jelezve ezen tudományágak müvelőinek fogékonyságát a területi kérdések iránt. Ugyanakkor sikerült a tágabb értelemben vett rokonszakmákon túl is szerzőket megszólítanunk; így üdvözölhettünk tavaly a folyó-

2. táblázat: A Tér és Társadalom szerzőinek szakterületi megoszlása, 2011 Disciplinary affiliation of Space and Society's authors, 2011

\begin{tabular}{lc}
\hline \multicolumn{1}{c}{ Szakterület } & A szerzók száma \\
\hline Társadalomföldrajz & 33 \\
Regionális tudomány & 13 \\
Közgazdaságtan & 10 \\
Szociológia & 8 \\
Urbanisztika & 6 \\
Közigazgatás-tudomány & 2 \\
Egészségtudomány & 2 \\
Fogyasztás-gazdaságtan & 2 \\
Néprajz & 2 \\
Demográfia & 1 \\
Irodalomtudomány & 1 \\
Történettudomány & 1 \\
\hline Szerzók összesen & 81 \\
\hline
\end{tabular}


irat szerzői közösségében például az egészségtudomány, a néprajz, az irodalomtudomány és a történettudomány szakterületeiről érkező kollégákat is.

A szerzőkről szóló összeállítás zárásaként név szerint is megemlítjük azokat, akik a tavalyi év folyamán tanulmányaikkal, beszámolóikkal és egyéb írásaikkal hozzájárultak a Tér és Társadalom 25. évfolyamának megjelenéséhez.

2011-ben szerzőink voltak:

$\begin{array}{lll}\text { Albel Éva } & \text { Illés Sándor } & \text { Pernyész Péter } \\ \text { Bakacs Márta } & \text { Jankó Ferenc } & \text { Probáld Ferenc } \\ \text { Barta Györgyi } & \text { Jakobi Ákos } & \text { Rácz Katalin } \\ \text { Baumann Tímea } & \text { Jaschitz Mátyás } & \text { Rátz Tamara } \\ \text { Beluszky Pál } & \text { Jelinek Csaba } & \text { Rechnitzer János } \\ \text { Berghauer Sándor } & \text { Kádár Kriszta } & \text { Rényi Zsolt } \\ \text { Berki Márton } & \text { Keller Judit } & \text { Sebestyén Tamás } \\ \text { Claval, Paul } & \text { Keményfi Róbert } & \text { Sikos T. Tamás } \\ \text { Czirfusz Márton } & \text { Kiss Norbert } & \text { Smahó Melinda } \\ \text { Csepeli György } & \text { Koszorú Lajos } & \text { Somlyódyné Pfeil Edit } \\ \text { Csomós György } & \text { Kovács András } & \text { Szabó Attila } \\ \text { Dudás Gábor } & \text { Kovács Sándor Zsolt } & \text { Szabó Balázs } \\ \text { Dusek Tamás } & \text { Kovács Zoltán } & \text { Szabó Tünde } \\ \text { Egedy Tamás } & \text { Kozma Gábor } & \text { Szántó Katalin } \\ \text { Enyedi György } & \text { Kőszegi Margit } & \text { Szilágyi Zsolt } \\ \text { Erőss Ágnes } & \text { Kövi Rita } & \text { Szirmai Viktória } \\ \text { Filep Béla } & \text { Kruzslicz Ferenc } & \text { Tagai Gergely } \\ \text { Forgács Tamás } & \text { Llera, Francisco } & \text { Tátrai Patrik } \\ \text { G. Fekete Éva } & \text { Lopez-Norez, Angeles } & \text { Tosics Iván } \\ \text { Gauder Péter } & \text { Mészáros Rezső } & \text { Uzzoli Annamária } \\ \text { Gémes Katalin } & \text { Michalkó Gábor } & \text { Váradi Monika Mária } \\ \text { Gyimesi Zoltán } & \text { Nagy Gábor } & \text { Varga Erna } \\ \text { Győri Ferenc } & \text { Nagy Terézia } & \text { Varjú Viktor } \\ \text { Győri Róbert } & \text { Nemes-Nagy Anna } & \text { Velkey Gábor } \\ \text { Gyuris Ferenc } & \text { Paládi-Kovács Attila } & \text { Vida Anikó } \\ \text { Horváth M. Tamás } & \text { Pálné Kovács Ilona } & \text { Vitrai József } \\ \text { Huszárik Erika } & \text { Parag Andrea } & \text { Wastl-Walter, Doris } \\ & & \\ & & \end{array}$

\section{A folyóirat lektorai 2011 -ben}

Az új szerkesztőség fontos célként tűzte ki, hogy a Tér és Társadalomhoz érkezett írások szigorúbb lektorálási folyamaton menjenek keresztül. Ezt a célt sikerült megvalósítanunk: sokféle szakmát képviselő, az ország (és Európa) 
3. táblázat: A Tér és Társadalom lektorai munkahelyük intézményi típusának megoszlása szerint, 2011

Workplace types of Space and Society's reviewers, 2011

\begin{tabular}{lc}
\hline \multicolumn{1}{c}{ A munkahely intézményi típusa } & A lektorok száma \\
\hline Egyetem/föiskola & 51 \\
MTA Regionális Kutatások Központja & 23 \\
MTA más kutatóintézete & 10 \\
Más kutatóhely & 2 \\
Állami szféra & 1 \\
Magánszféra & 3 \\
\hline Lektorok összesen & 90 \\
\hline
\end{tabular}

számos településén, különböző intézményekben dolgozó kollégánk vállalta a lektorálási tevékenységet.

A TéT lektorainak intézmények szerinti megoszlása a szerzők munkahelyi típusához hasonlóan alakult (3. táblázat). Kilencven lektorunk több mint felének munkája valamely egyetemhez, illetve főiskolához köthető. A Tér és Társadalom szerkesztősége számára különösen örömteli, hogy RKK-s kollégáink közül sokakat sikerült bevonni a lektorálási folyamatba - a huszonhárom lektor a Regionális Kutatások Központja kutatói állományának körülbelül felét jelenti. Emellett az MTA más kutatóintézeteinek (Földrajztudományi, Szociológiai, Történettudományi, Kisebbségkutató Intézet stb.) és további kutatóhelyek (pl. KSH, WIIW - Ausztria) munkatársai, illetve a kutatói körön kívüli szakmabeliek is hozzájárultak a lektori tevékenység kiszélesítéséhez.

Lektorainkat a Tér és Társadalom szerzőihez hasonlóan nemcsak Magyarországról, hanem külföldi kutatóintézetekből és egyetemekből is sikerült bevonnunk a bírálati folyamatba, többek közt Heidelbergből, Bécsből, Kolozsvárról és Újvidékről (2. ábra). Magyarországi lektoraink területi megoszlása a szerzők esetében bemutatott helyzetképhez hasonlóan ugyancsak elsősorban a kutatóintézetek és felsőoktatási intézmények elhelyezkedését képezi le. Budapest súlya ebből a szempontból is meghatározó, hiszen 2011-ben a TéT lektorainak mintegy fele innen „származott”. A kisebb vidéki egyetemi központok (pl. Sopron, Veszprém, Gödöllő) mellett a nagyobb vidéki felsőoktatási centrumokból - részben RKK-s kutatóhelyekről - (Győr, Pécs, Szeged, Miskolc) sikerült nagyobb számban kollégákat lektori tevékenységre felkérni. Ezen túlmenően a további RKK-s bázisok (Kecskemét, Békéscsaba) munkatársai is aktívan kivették részüket a lektorálási folyamatból.

A Tér és Társadalom 2011-es lektorai nélkül, akik szakmai tudásuk legjavát nyújtva időt és energiát szántak az írások értékelésére, a folyóirat színvonalának fenntartása és növelése nem lett volna lehetséges. A szerkesztőség és a szerzők nevében ezúton is nagyon köszönjük az olvasók számára szinte láthatatlan, de nagyon fontos munkájukat. Az írások alapos olvasószerkesztése, amelyet Marosi Lajos végez, szintén nagymértékben javította a cikkek stiláris színvonalát. Külön köszönjük Thomas Richersnek az angol nyelvű absztraktok javítását. 
2. ábra: A Tér és Társadalom lekłorainak (munkahelyek szerinti) területi megoszlása, 2011

Spatial distribution of Space and Society's reviewers (according to workplace), 2011

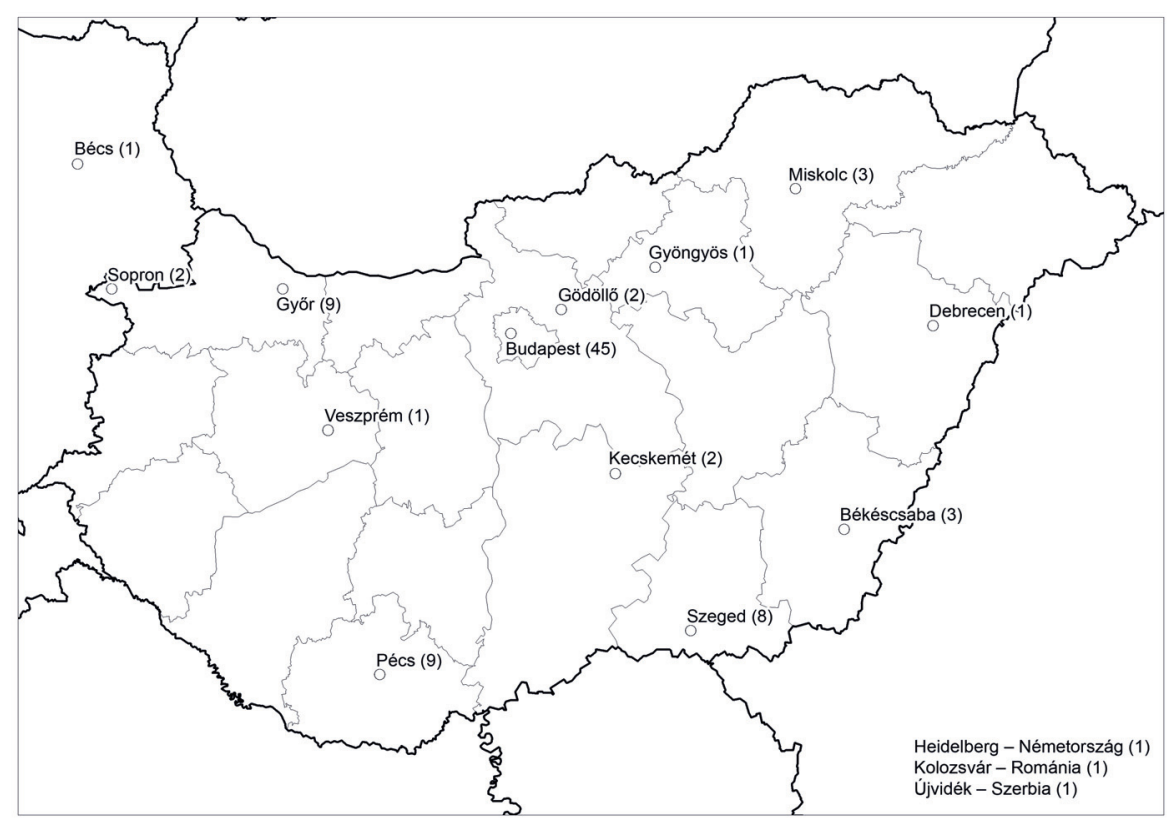

Arra törekedtünk, hogy teljes listát állítsunk össze azokról, akik tavaly lektori tevékenységet végeztek a folyóirat számára. Amennyiben valakit mégis kihagytunk, kérjük, jelezze a szerkesztőség számára, hogy kiegészíthessük a névsort.

2011-ben lektoraink voltak:
A. Gergely András
Csanádi Gábor
Frisnyák Zsuzsa
Ábel István
Csatári Bálint
G. Fekete Éva
Bajmócy Péter
Csizmadia Zoltán
Gál Zoltán
Bajmócy Zoltán
Deák Endre
Gödri Irén
Barta Györgyi
Dőry Tibor
Grosz András
Beluszky Pál
Dusek Tamás
Benedek József
Ekéné Zamárdi Ilona
Bernek Ágnes
Fábián Attila
Hardi Tamás
Boros Lajos
Bottlik Zsolt
Faragó László
Feischmidt Margit
Bőhm Antal
Fleischer Tamás
Bucher Eszter
Földi Zsuzsa
Bujdosó Zoltán
Győri Róbert
Czakó Erzsébet
Gyuris Ferenc
Hegyi Barbara
Honvári János
Hunya Gábor
Jakobi Ákos
Czirfusz Márton
Hajdú Zoltán
Jancsik András
Jankó Ferenc
Jeney László
Kiss Éva
Korompai Attila 
Kotosz Balázs

Kovács Katalin

Kovács Teréz

Kovács Zoltán

Kukely György

Laky Ildikó

Lengyel Balázs

Lengyel Imre

Lőcsei Hajnalka

Nagy Erika

Nagy Gábor

Nagy Imre

Nagyné Molnár Melinda

Nemes Nagy József

Nikodémus Antal
Lukács Eszter

Lux Gábor

Mezei István

Michalkó Gábor

Nagy Beáta

Osváth László

Pál Viktor

Pálné Kovács Ilona

Péntek Márta

Perger Éva

Pikó Bettina

Probáld Ferenc

Pusztai Bertalan

Ságvári Bence

Sikos T. Tamás
Somlyódyné Pfeil Edit

Szabó Julianna

Szalkai Gábor

Szarka László

Szerb László

SzörényinéKukorelli Irén

Tagai Gergely

Tátrai Patrik

Timár Judit

Tosics Iván

Uzzoli Annamária

Vajda Zsuzsa

Váradi Monika Mária

Vigvári András

Wilhelm Zoltán 


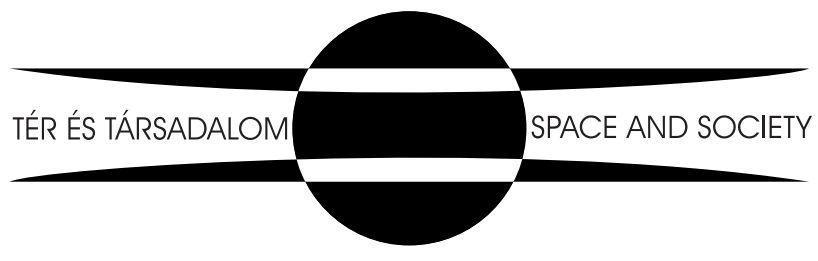

